\title{
The Causes and Consequences of the Federal Student Financial Aid Policy Shift from Grants to Loans
}

\author{
Matt Melvin and Sheldon L. Stick
}

Access to higher education is often influenced equally by a person's ability and motivation as well as financial resources. The history of how student financial aid emerged as a major issue in American education is discussed with attention to why a policy of student financial aid was initiated, what it was intended to accomplish, how national priorities influenced those policies, and the current status of existing practices. New or transitioning college and university students should find this an informative and revealing discussion, as they serve as a clearinghouse for information on financial assistance.

Student financial aid touches all aspects of higher education, reaching to the core of American Society and markedly influences opportunities to get ahead. Considering its importance and pervasive influence, it is striking to realize financial aid policy was founded on a coherent philosophical base. At the government level, it has tended to reflect disjointed, transitory programs targeted at momentarily popular national social goals. Bowman and Fenske (1982) claimed student aid was a classic example of the American genius for "muddling through." Although differentially implemented, the intent has been lofty and has frequently had altruistic results. Accountability tended to be questionable, but the high-minded goal of such efforts generally submerged concerns about coherent management.

During the past several years there has been marginally increased concern about the availability of financial aid for college students to pursue further education. Families and often the students themselves generally saved money during the years preceding high school graduation, and the US economy was favorable toward encouraging such thrift. Monetary shortfalls for attending college tended to be viewed with indifference because of the belief money would always be available to borrow and the prospects for meeting mature loans were bright.

The past year has witnessed a dimming of the glow from the US economy. Money continues to be available for financing higher education, but the enthusiasm for borrowing has dampened. Further muffling the interest in borrowing is the growing awareness of rising costs associated with higher education. Attracting, enrolling, and retaining students often has been elevated to a position of marked importance, and many institutions are making major investments in marketing and advertising programs. Exacerbating the pressures on colleges and universities is the phenomenal growth of using technology as an adjunct or primary means for providing learning opportunities.

The effectiveness of computer-mediated learning and heightened respectability

Matt Melvin, MS, is the Assistant Dean/Director of College Advancement at Kansas State University-Salina. Sheldon L. Stick, PhD, is a Professor of Educational Administration at the University of Nebraska-Lincoln. 
accorded to community colleges is a direct challenge to conventional modes for higher education. Both can be expected to continue taking larger bites from the tuition and housing revenues formerly directed to colleges, and both show evidence of enhanced prominence. Students considering the pursuit of higher education should be aware of the financial nuances associated with the transition from a K-12 level of education. Seldom do potential new students have opportunities to attend orientations designed to prepare them for the fiscal realities of continuing their education. For students attending school away from their home, seldom do they have the opportunity for a careful study of the community where they will live. For students making commitments to attend an institution, seldom are they provided with information on projected conditions of the institution apt to affect the support systems commonly expected (student services, library, technology, curriculum, etc.).

A decision to enroll in a college rarely involves one person. Instead, there are immediate and extended family members, friends, employers, and even lending agencies. What happens to the student has a ripple affect and sends messages to others. When non-traditional students commit to attend a college or university it sets into activity some of the same phenomena, but there can be special events initiated, depending upon the nature of the student and degree of exceptionality. At one end of such a continuum might be the older adult returning to school. At the other extreme there could be students with challenging circumstances requiring adaptation of conditions to allow them the opportunity for maximizing their earning potential. The process of orienting students to a new learning environment is of paramount concern, but too often receives cursory attention from a student and the providing institution. Adding to all of the changes in a student's life is the frequently unspoken or unwritten expectation of faculty. Society benefits from a well-informed and educated citizenry. Knowledge and access to learning generally has been seen as pivotal for enhancing a person's prospects for taking a responsible role in the further advancement of society and enhancing self. Higher and postsecondary education has been the door most people pass through on their way toward becoming fully developed and contributing members of society. This discussion focuses on existing federal policy as it has affected student financial aid and implications of those policies.

During the past 40 years, higher education federal financial aid has undergone a dramatic policy shift. Starting as a vehicle to provide educational access for the economically disadvantaged, it became more centralist and began serving as a means to broaden choices and eventually providing conveniences to increasing numbers of students from the middle socioeconomic class. At no point in time has Congress or a sitting President expressly stated the purpose of financial aid changes, but increasingly, it has become a middle-income program with a component for low-income students (King, 1996).

During the 1980s and into the 1990s, the US government incurred huge budgetary deficits, created largely by the expenditures in defense and the growing pressures from selective social programs. In response to such monetary demands, the Federal Government pursued a practice of increasingly shifting responsibilities for social and educational programs to individual states, who were not prepared to assume the sudden 
and growing demands for tax dollars. Law, regulations, and the most pressing social issues influenced states in their responses to the new and unwelcome fiscal obligations. Financing higher education often was viewed as a discretionary commitment, and the result was a move toward shifting more of that burden to students.

Steadily, and almost imperceptibly, prisons and welfare program funding replaced higher education in the states' budgets. Fiscal exigencies and new questions about the value added to society by graduates from higher education negatively influenced and often changed the public and legislative beliefs about higher and postsecondary education being a public good (Parsons, 2000). Perceptions increasingly were jaundiced because of reports graduates were unable to demonstrate requisite skills and knowledge required by a society that was dramatically becoming more technological and information based. Coupled to those growing concerns was the attitude about education being primarily a benefit for the graduates whose lifetime earnings grew increasingly and disproportionately larger than the earnings of high school graduates and much larger than students who were high school dropouts.

Keynes (1995) reported many people held the belief an earned college degree benefited those who held the degree the most, and those beneficiaries were the people who should be expected to pay more of the costs associated with the education. The prevailing opinions were that it was an investment with an unequivocal benefit. College was not a right but an earned entitlement, and as such carried (implicitly) the obligation for personal involvement in the funding of such an advantage. Higher education reached an unparalleled position when it was seen as a consumer product rather than a social good whose benefits were publicly shared (Parsons, 2000).

The change in legislative and public opinion regarding the purposes and benefits of higher education had a momentous impact on refocusing federal financial aid policy. This was most apparent by the shift from providing students with grants and fellowships to requiring them to obtain loans (Parsons, 2000). Unfortunately, not all students want or qualify for loans and many are forced to obtain part-time or even full-time work in order to attend college. The paradox created was that academic and vocational performance often have not reflected true talent because added burdens from working or fulfilling multiple familial obligations erode many students' opportunities for displaying their abilities maximally.

Since the inception of the federal education loan program in the mid-1960's, students and their parents have borrowed more than $\$ 300$ billion to finance the cost of attending college. American families required nearly 30 years to borrow the initial half of this amount, but only five years to borrow the second $\$ 150$ billion (Scherschel, 2000). Guaranteed student loans now comprise the single largest source of financial aid totaling more than five times the Pell Grant program, which was meant to be the system's foundation. Even those most at-risk (low-income, students in remediation, students taking short-term training with uncertain economic return) increasingly must borrow to gain access to additional educational opportunities. 
The passage of the Higher Education Act (HEA) of 1965 marked the beginning of higher education's emergence as an independent policy issue supported by its own policy arena (Parsons, 2000). That legislation established a commitment to help the disadvantaged through need-based grant programs while helping middle class families through government sponsored loans. The HEA of 1965, subsequently augmented by the 1972 amendments, provided aid directly to students, rather than an institution, legislated Educational Opportunity Grants for students from the lowest socioeconomic strata, and allowed subsidized loans for lower-middle class students.

The policy was driven by two social policy views. One was the US, as an advancing nation, needed to invest in and develop its human capital. The other was that bright but poor young persons, especially minority students, should be able to gain additional learning opportunities in the same or a highly similar manner as a student from a more affluent family (Keynes, 1995). The passage of the 1965 act was the result of a growing national concern for the welfare of underprivileged Americans and a belief that education was the key to becoming a fully participating member of society. The federal government was seen as the responsible party for ensuring all Americans had equal access to the ladder of success (Bowman \& Fenske, 1982).

Amendments to the HEA of 1965 greatly expanded support for student assistance and signaled a continued national emphasis on student access and choice. New programs were conceived as part of Lyndon Johnson's War on Poverty. The 1972 amendments broadened the policy objectives to access and choice and established the Federal Government as the bedrock in student aid (Cofer \& Somers, 2000). The centerpiece of the 1972 amendment was the creation of the Pell Grant; a direct form of aid to students designed to cover most of the costs of attendance at a public college or university (King, 1996).

The drift toward a loan-centered system began in 1978 when Congress passed the Middle income Student Assistance Act. That piece of legislation modestly expanded eligibility for Pell Grants, and made subsidized loans substantially more available to any student regardless of demonstrated income or need (Gladieux \& King, 1999). The emphasis toward loans was exacerbated as the rapid growth in federal aid characterizing the 1970's came to a halt at the start of the 1980's (Hansert, 1991)

The 1980 election and subsequent change in economic priorities dramatically affected federal policy in higher education and the congressional policy-making process. The newly elected Republican President and Senate, with the aid of conservative members in the House, initiated a sweeping program reduction in federal expenditures, except for defense. During that period, the shape, if not the stated intention, of student assistance changed from grants to loan (Linsley, 1997). During the 1970's, 76\% of federal student financial aid was in form of grants and 20\% in loans. By the mid 1980's, that ratio had been almost reversed, with loans accounting for $67 \%$ and grants $29 \%$ of federal financial aid (Hannah, 1996).

The value and significance of federal support in making college affordable was further eroded because Congressional appropriations failed to keep pace with the rapid 
increases in tuition (Hartle, 1990; Gladieux, 1992). The disparity between rising costs and falling student aid resulted in an expanding need-gap (Bowman \& Fenske, 1982). As a result, the purchasing power of federal student assistance actually declined for several years during the Reagan administration (Hanset, 1991).

The 1992 reauthorization to the HEA was notable because it sought to correct the problems created by earlier social, economic, and political environments. College costs had grown at a rate that outpaced inflation, Pell Grant allocations had been flat with regard the buying power against rising tuition, and participation of students enrolled in proprietary schools in the Guaranteed Student Loan Programs witnessed a dramatic increase. One consequence from the earlier unwritten policies was an appreciable decline in ability of students from low and moderate-income families to attend college without incurring considerable debt. With the 1992 HEA reauthorization, Congressional leaders showed their desire to restore a reasonable balance between grants and loans. The prospect of a cold-war peace dividend fueled hopes Pell Grants might be turned into an entitlement or mandated spending program, with automatic annual increases for inflation (Gladieux \& King, 1999).

The 1992 election year dynamics was seen as a favorable influence on the reauthorization process. Cross currents and constraints of the existing political, social, economic and intellectual environments continued working against those wanting to restore the HEA commitment to needy students, and favored those who sought support through a broader constituency (Hannah, 1996; Gladieux, 1992). The 1992 HEA reauthorization created an unsubsidized loan option, not restricted by need, intended to make loans available to middle-income students who had been squeezed out of eligibility for the regular subsidized loan. Also, the 1992 changes provided better loan terms for independent students and increased the annual aggregate loan limits for both independent and dependent students (Schersel \& Behymer, 1997).

The principal impact of the 1992 legislation was clear: far from correcting the grant/loan imbalance, it expanded borrowing capacity for students and parents at all income levels (Gladieux \& King, 1999). The politics surrounding the 1992 HEA resulted in a significant shift in federal policy; from promoting access to postsecondary education through grants based on need to a broader policy of insured loans regardless of family income. As a result, the volume of unsubsidized loans more than doubled during the 1990s (Scherschel \& Behmeyer, 1997).

\section{Impact of Policy-Shift on College and Major Choice and Lifestyle}

Increasing reliance on loans as the foundation for student aid has become a growing concern for students, parents, and some policy makers. The unprecedented pace of student borrowing under the federal education loan programs during the 1990s raised concerns about the ability of many students to manage their post-college debt burdens, and left families wondering when they would be freed from the financial burdens associated with raising and educating their children. Nagging questions about the prospect of hefty student loan payments forced a generation of college students, especially those interested in pursuing graduate education, to restrict choices, alter career 
plans, and fundamentally change family and lifestyle plans. A growing fear emerged that the bigger post-college debt burdens would require borrowers to allocate increasingly larger amounts of discretionary income to a monthly student loan payment, thus reducing their financial capacity to buy cars, purchase and furnish homes, start a family, save for their children's educational expenses, and build a retirement fund. Of greater concern was the belief many individuals and families were electing to avoid higher education because of an unwillingness to make the investment and face the prospect of carrying heavy financial obligations (Scherschel \& Beymer, 1997).

\section{Access}

The impact of federal financial aid policy on access and persistence has been inconclusive. Borrowing the money has been problematic for some students, especially those with marginal financial resources and other monetary obligations. Additionally, students who believed themselves to be high-risk for success in academic or vocational learning environments have tended to avoid incurring pressures associated with additional education. Such individuals generally have not been aware of potential opportunities for funding their higher education, nor have they been sought aggressively by educational counselors as prospects for additional education. Scherschel and Behymer (1997) claimed a majority of students who took on the obligation of student loans eventually earned a return on their higher education investment so significant as to make the debt manageable. They cited data from a survey reporting 8 of 10 students believed their loan debt was manageable, even when they had borrowed up to $\$ 20,000$.

Lenders have generally offered students flexible ways to repay their loans and more assistance if they encountered repayment difficulties (Keynes, 1995). Thus, for most students borrowing has been a good investment. Information was not provided in the Scherschel and Behmyer (1997) study on the attitudes of students or families who had or were contemplating educational loans in excess of $\$ 20,000$. Those circumstances often happened when an individual elected to matriculate at private or non-urban institutions, when residential costs were factored into the equations, or when non-traditional students were enrolling or returning to school.

Although the amount of student indebtedness has increased since the HEA of 1992, the debt-to-earnings ratio apparently has changed only moderately. Gladieus (1992) contended individuals investing in education and training would gain sufficient future earning power to make the repayment of accumulated indebtedness without the obligation being unduly burdensome. Additionally, Linsely (1997) and St. John and Noell (1989) claimed the increased availability of loans helped promote access and enhanced choices for middle-income students as well as for independent adults returning to higher education.

\section{Underrepresented Students}

People at different income levels have responded differently to the shift in financial aid financing (Linsely, 1997). The major reductions in grant programs and shift to loans 
as the primary source of support for financing higher education was viewed as a potential barrier to access, persistence, and eventual graduation rates for a large number of students from the traditionally underrepresented populations. While loans have served as a viable source of financing for middle and upper-income students, the current federal financial aid policy has served to reduce the options available for low and middle-income students deliberating about future learning opportunities. Hartle (1997) contended the goal of expanding access to higher education was being jeopardized by the change in how support was being provided.

The growth in poverty and continued under-representation of African-American, Native-American, and Hispanic students in higher education, as well as their continuing levels of academic attrition, probably are not unrelated to the federal policy for making financial aid available to students (Lloyd, 1989). The gap in college attendance between individuals from high versus low socioeconomic backgrounds has changed little during the past three decades. During that same period of time, students from the middle-socioeconomic strata have been provided with unparalleled opportunities to attend and persist in college. Despite programs of federal aid and the enormous efforts made by colleges and universities, the relationship between family income and enrollment remains as clear and unambiguous as it was in the mid-1960s.

Higher family income has continued to be positively related to the likelihood students will attend college, the kind of college they will attend, and their chances of being graduated (Hartle, 1997). Encouraging such families or individuals to assume substantial financial obligations, through student loan programs, has not been productive in making a notable change in the ratio of students seeking advanced learning experiences. Also, despite the initial overtures from higher education institutions, persistence and eventual success for many students from underrepresented and lower income strata has depended extensively on the solvency of special programs that support students and faculty sympathetic to their needs. At this time there is little evidence either has much favor.

Current student aid programs have been inadequate for low-income students (Somers \& St. John, 1997) in terms of the dollar amounts, manner of distribution, and support services available during the process of program completion. Concerns about undertaking loans in significant amounts influenced both the attitudes toward entry and ability for persistence of minority and low-income students. As the purchasing power of Pell Grants declined, low-income students interested in further education and learning experiences have found themselves with restricted choices. Borrowing has continued to be a difficult choice for low-income and many minority students, who often were hesitant to assume financial burdens for fear of taking on debts they might not be able to repay. For many, the educational system has not been readily accessible, nor has it been particularly kind. Overcoming distrust and even fear of the system has been and continues to be a severe hurdle made even more pronounced by the shift from grants to loans (Somers \& St. John, 1997; King, 1999). As a result, the federal student aid system seemingly has been a major contributor to continuing the inequalities of opportunity it was created to serve (King, 1996). 
Financial considerations influence individual decisions on whether to attend higher education and where to enroll (Porter, 1991). Increasing emphases on student loans as the vehicle of choice for funding college has been a dominant influence on institution selection among many middle-income students and even some from high-income families. Schershel and Behymyer (1997) reported 54\% of the subjects surveyed (students from middle and upper income families) had concerns about borrowing large amounts of money and it prevented them from applying to and attending more expensive institutions. Prospective students often have perceived the costs of going to a private college as prohibitive and therefore do not include such institutions in their initial search process. Interestingly, once enrolled, college students and their families seem more inclined to assume increasing levels of debt, but there has been an undefined limit beyond which they refused to pass.

The amount of debt carried by private college students and their families has a marked and negative impact on within-year persistence. In the short-term, particularly a current academic year, both public and private school students apparently were willing to borrow money to attend college, and at an increasing rate. Such current-year borrowing appeared to be minimally affected by the influence of tuition increases. In the case of private school students the accumulated affect of yearly borrowing decreased the likelihood of continued enrollment (Cofer \& Somers, 2000). Such shifting in enrollments could inevitably result in a greater stratification at private institutions with more students from affluent families and more poor, but able, students who qualify for large amounts of need-based aid (Keynes, 1995). Students from the middle socioeconomic strata have tended to withdraw from expensive environments, and if they returned to continue their education it was likely to be done at a public institution.

In their quest to decrease or minimize loan debt, many students have chosen to attend lower-priced community colleges, often on a part-time basis, while working. Alternatively, many students have elected to matriculate at public colleges but do so as part-time students during a prolonged time period. However noble such efforts seem, they do not contribute to student persistence and academic or vocational success. Combining long hours at work with part-time attendance has tended to limit participation in some programs of study, and research has shown that students who work long hours and attend classes part-time were less likely to complete a degree or program (King, 1999). When the consistently incremental costs for tuition and materials are married to the current loan-based system for funding higher education, the attractiveness of federal need-based aid lost much of its luster, especially for many underrepresented students and others from low socioeconomic environments (Somers \& St. John, 1997). Exacerbating the situation has been the recognition that many attractive programs of study require students to be in attendance during the majority of the daytime hours. Special accelerated undergraduate and graduate programs generally are costly and have accompanying stringent admission criteria, and for working students and many from underrepresented pools those standards serve as imposing barriers. 
St. John (1994) reported students interested in majors such as social work and education tended to be hesitant about making such commitments when confronted by potential debts, and whenever possible opted for more financially lucrative majors and careers. The impact of sufficient numbers of student exercising such options over an extended period of time can translate into discipline shortages, or leaving the lower paying career choices available to a defined group of students. Throughout the United States there are reported shortages in professions such as Education and Nursing; two disciplines characterized by low pay. Both have tended to rely upon traditional methods for educating professional; extensive daytime involvement and at prescribed times and locations. Ironically, available research has been interpreted as showing students' actual and expected debt burdens were not related highly with the selection of a particular undergraduate major (St. John, 1994). The influence of debt burden on academic major merits additional scrutiny and should be routinely monitored, particularly as debt levels continue to rise.

\section{Lifestyle}

Despite its faults, federal financial aid has provided students, lacking the financial resources to attend college, with a way to invest in their future. While borrowing may be a problem for some, a majority of students apparently have earned enough of a return on their initial investment in higher education to mitigate concerns. Data across a range of debt levels has been interpreted to mean a majority of borrowers leave school with debt levels well below their statutory maximums (Scherschel, 2000). Some researchers also contended that borrowing did not appear to affect major lifestyle choices such as the time of marriage, or purchases such as car or house (Choy \& Carroll, 2000).

\section{Future Concerns and Issues}

1. Lender experience with debt burden and defaults revealed payment difficulties emerged when payments represented over $8 \%$ of a borrower's gross monthly income. During the past five years, the percentage of borrowers with substantial debt levels (over $\$ 10,000$ ), adjusted for gross income, has risen steadily. Heavily indebted graduate students rose from $46 \%$ to $62 \%$, and among undergraduates the change was from $19 \%$ to $40 \%$. The number of proprietary students with heavy debt quadrupled to $31 \%$, while the community college group tripled from $2 \%$ to $9 \%$ (Scherschel, 2000). Forecasts are that that starting salaries of new graduates are unlikely to increase dramatically in the foreseeable future, which means the debt-to-income ratio of many borrowers will result in people having difficulties repaying their loans, particularly during their early repayments years (Keynes, 1995).

2. Borrowers need to understand the impact of student loan payments on their post-school budget and lifestyle. The growing ranks of heavily indebted borrowers underscores the need for more targeted loan counseling services and materials. Given 
the increased reliance on unsubsidized loans, today's borrowers would be well served by more information on how to minimize the interest accrual on these debts.

3. Renewable scholarships and grants are needed. The balance between grant and loan support should be shifted back toward the grant side. One of the more consistent findings in the persistence literature concerning student aid is the favorable impact of grants as opposed to loans. Manipulating the student aid system to increase grant assistance, to provide more on-campus work-study and self-help support, and minimize the use of loans as the sole or major source of aid has the potential to increase access, persistence, and ultimately, program or degree completion. Loans are a viable part of the federal approach and should be continued, but as part of packaging that begins with family contribution, grant and college work-study, and not as the principle source of support (Porter, 1991).

\section{Conclusions}

The federal financial aid policy arena currently is divided into two groups based on beliefs about the proper role of government in education. Regardless of political inclination, it is doubtful the financial aid policy arena will be benefited by an influx of federal student aid. The ideological differences in the arena are more disparate than at any time since the 1950's, and the potential for divisiveness increases as group members unite around and defend their beliefs (Parsons, 2000).

As the loan debt for students at all types of institutions continues to increase, the impact of federal financial aid policy, particularly on those historically underrepresented in higher education, must be monitored continuously. Policies need to meet their initially created goal of increasing access and choice for all students regardless of race or income. If trends continue, participation in the economic growth and social progress associated with and expected from higher education increasingly will be limited to those with the financial resources to take advantage of educational opportunities. Instead of fulfilling the promise of equal opportunities for all by crafting a smooth highway for transitioning students from secondary to higher education, current financial aid policy has the potential to further widen the socioeconomic gap between the rich and poor. Society relentlessly is moving toward an information and knowledge-based economy. Casper (1995) wrote that higher education might be the last best hope for a transfigured society but to reach such goals all participants of a society need to know the rules of the game and have access to the same field of play.

\section{References}

Bowman, R., \& Fenske,R. (1982). Federal policy for higher education and the dilemma of student financial assistance in the 80s. Journal of Student Financial Aid, 12 (2), 7-17.

Casper, G. (1995). Come the millennium, where is the university? Paper presented at the Annual meeting of the American Educational Research Association, San Francisco, CA. 
Choy, S., \& Carroll, C. (2000). Debt burden four years after college. (NCES 2000188). Washington DC: U.S. Department of Education Office of Educational Research and Improvement.

Cofer, J., \& Somers, P. (2000). A comparison of the influence of deltoid on the persistence of students and public and private colleges. Journal of Student Financial Aid, 30(2), 23-38.

Gladieux, L. (1992). Bright hopes and paper promises: The changing nature of student aid policies in the 90s. College Board Review, 164, 14-32.

Gladieux, L., \& King, J. (1999). The federal government and higher education. In P.

Altbach, R. Berdahl, and P. Gumport (eds.). American Higher Education in the TwentyFirst Century. Social, Political, and Economic Challenges (pp. 151-182).

Baltimore: Johns Hopkins.

Hannah, S. (1996). The higher education act of 1992: Skills, constraints, and the politics of higher education. Journal of Higher Education, 67(5), 498-527.

Hansert, J. (1991). The roots of federal student aid policy. New Directions for Higher Education, Number 74, 3-19.

Hartle, T. (1990). Federal support for higher education in the 1990s, boom, bust, or something in between. Change, 22, 32-41.

Hartle, T. (1997). The end of equal opportunity in higher education. College Board Review, 181, 8-15.

Higher Education Act of 1965 (20 U.S.C. $\S 1070-1099$ ).

Higher Education Amendments of 1972. In Thomas, S. (Ed.). (1994). The Yearbook of Educational Law 1994. Topeka, KS: National Organization on Legal Problems of Education.

Higher Education Amendments of 1992 (106 Stat. 448).

Keynes, J. (1995). Are students borrowing too much? Planning for Higher Education, $23,35-42$.

King, J. (1996). Student aid: Who benefits now? Educational Record, 77, 21-27.

King, J. (1999). Money matters: The Impact of Race/Ethnicity and Gender on how Students Pay for College. Washington, DC: American Council on Education.

Linsely, C. (1997). The underpinnings of student aid. New Directions for Institutional Research, Number 95, 5-23.

Lloyd, A. (1989). Who gets what? Impact of financial aid policies. Research in Higher Education, 30 (5), 471-483.

Middle Income Student Assistance Act of 1978 (92 Stat. 2402).

Parsons, M. (2000). The higher education policy arena: The rise and fall of a community. In Losco, J., \& Fife, B. (Eds). Higher Education in Transition: The Challenges of a New Millennium (pp. 83-108). Westport, CT: Bergin and Garvey.

Porter, O. (1991). Where do we go from here: Looking beyond student aid and access to persistence. New Directions for Higher Education, Number 74, 75-90.

Scherschel, P. (2000, June). Student indebtedness level continues to rise: Stafford indebtedness 1999 update. Indianapolis, IN: USA Group Foundation. 
Scherschel, P., \& Behymer, P. (1997). Reality bites: How much do students owe? Indianapolis, IN: USA Group Foundation.

Somers, P., \& St. John, E. (1997). Interpreting price response in enrollment decisions: A comparative institutional study. Journal of Student Financial Aid, 27 (3), 15-36.

St. John, E. (1994). The influence of debt on choice of major. Journal of Student Financial Aid, 24(1), 5-12.

St. John, E., \& Noell, J. (1989). The effects of student financial aid on access to higher education: An analysis of programs with special consideration of minority enrollment. Research in Higher Education, 30, 563-581. 